\title{
EFEKTIVITAS MODEL PROBLEM BASED LEARNING DAN DISCOVERY LEARNING TERHADAP BERFIKIR KRITIS PADA PEMBELAJARAN MATEMATIKA: KAJIAN META-ANALISIS
}

\author{
Maulida Anggraina Saputri \& Theresia Sri Rahayu \\ Universitas Kristen Satya Wacana \\ 292017041@student.uksw.edu ,theresia.rahayu@uksw.edu
}

\begin{abstract}
This study aims to determine the effect of level differences in Problem Based Learning and Discovery Learning model on student's critical thinking by meta-analysis studies in Mathematics learning, by collecting several relevant journals through Google Scholar. This study uses the Ancove Test to determine the average difference Test in learning model, which has met the Prerequisite Test, then the Effect size is calculated. The result is normal, homogeneous and linear data were obtained with a significance value>0,05. In Ancova Test, the result Discovery Learning is more effective than Problem Based Learning. This is obtained from the results of the posttest scores of 78.4450 for the Problem Based Learning and 83.5840 for the Discovery Learning models. At the Fcount obtained is 7,181, and the Ftable obtained is 3,59, it can be stated that Fcount $>$ Ftable, namely with a value of 7,181 $>3,59$ and significance of 0,016 <0,05. From these results prove that there is a significant difference between the Problem Based Learning and Discovery Learning models on student's critical thinking in Mathematics learning. In determining the Effect size, it produces a value of 0,0302, it can be stated a moderate influence on student's critical thinking in Mathematics learning.

Keywords: Problem Based Learning, Discovery Learning, Critical Thinking, Meta-analysis
\end{abstract}

\begin{abstract}
Abstrak: Penelitian ini bertujuan untuk mengetahui pengaruh tingkat perbedaan model Problem Based Learning dan Discovery Learning terhadap berfikir kritis siswa menggunakan kajian meta-analisis pada pembelajaran Matematika, dengan mengumpulkan beberapa jurnal relevan yang dicari melalui Google Cendekia. Penelitian ini menggunakan Uji Ancova untuk menentukan Uji beda rata-rata pada model pembelajaran, yang sudah memenuhi Uji Prasyarat terlebih dahulu, kemudian dihitung Effect Size-nya. Dari penelitian ini diperoleh data yang normal, homogen dan linear dengan perolehan nilai signifikasi $>0,05$. Dalam Uji Ancova menghasilkan Discovery Learning lebih efektif dibandingkan dengan Problem Based Learning hal tersebut diperoleh dari hasil nilai posttest 78,4450 untuk model Problem Based Learning dan 83,5840 untuk model Discovery Learning. Pada Fhitung yang diperoleh adalah 7,181 dan Ftabel yang diperoleh adalah 3,59, maka dapat dinyatakan bahwa Fhitung $>$ Ftabel yakni dengan nilai 7,181 > 3,59 dan signifikasinya $0,016<0,05$. Dari hasil tersebut membuktikan bahwa terdapat perbedaan yang signifikan antara model Problem Based Learning dan Discovery Learning terhadap berfikir kritis siswa pada pembelajaran matematika. Dalam menentukan Effect Size menghasilkan nilai 0,302, maka dapat dinyatakan
\end{abstract}

Fondatia : Jurnal Pendidikan Dasar

Volume 5, Nomor 1, Maret 2021; 85-94

https://ejournal.stitpn.ac.id/index.php/fondatia 
bahwa model Problem Based Learning dan Discovery Learning memberikan pengaruh yang tergolong sedang terhadap berfikir kritis siswa pada pembelajaran Matematika.

Kata Kunci: Problem Based Learning, Discovery Learning, Berfikir Kritis, Meta-Analisis

\section{PENDAHULUAN}

Manusia tidak akan bisa lepas dari pendidikan. Menurut Mustofa (2015:6) Pendidikan berasal dari kata "didik" yang kemudian mendapatkan awalan mesehingga menjadi kata "mendidik" yang memiliki arti sebuah usaha memelihara dan memberikan sebuah pelatihan-pelatihan. ${ }^{1}$ Maka dari itu Pendidikan merupakan sebuah usaha yang dilakukan seseorang dalam mengembangkan segala sesuatu yang berdampak positif bagi manusia melalui pengajaran, pelatihan serta pembelajaran. Pembelajaran dilaksanakan oleh siswa bukan dibuat untuk siswa, jadi dalam kegiatan pembelajaran guru sangat berperan penting. Maka dari itu, pemerintah berupaya dalam meningkatkan mutu pendidikan sekolah dengan cara perbaikan proses belajar mengajar yang berkualitas. Untuk saat ini Indonesia menggunakan kurikulum 2013 dalam proses pembelajaran. Tujuan dari pembelajaran dengan Kurikulum 2013 ini agar siswa memiliki kepribadian yang lebih berkarakter, serta sekolah lebih dituntut untuk menciptakan siswa yang mampu berfikir kritis, dalam menciptakan siswa berfikir kritis tidak hanya merubah metode dalam mengajar tetapi ada tanggung jawab sebagai guru dalam membiasakan siswanya untuk berfikir kritis.

Menurut Asriningtyas (2018:25) Berfikir kritis merupakan kemampuan berfikir tingkat tinggi pada seseorang atau siswa yang dapat memecahkan permasalahan secara tepat dan logis. ${ }^{2}$ Peserta didik yang mempunyai keterampilan berfikir kritis dapat membuat suatu pertimbangan dengan baik untuk mengambil suatu keputusan. Menurut Wijaya dalam (Wahyu Wulandari 2011), terdapat 5 aspek pengukuran dalam kemampuan berfikir kritis, yaitu: mengenal permasalahan secara rinci, menentukan permasalahan, merencanakan strategi, mengumpulkan data untuk pembuktian, dan

${ }^{1}$ Mustofa, Model Pendidikan dan Pelatiban Konsep dan Aplikasi (Bandung: Alfaberta, 2015).

2 Asriningtyas, A.N.,Kristin,D., \& Anugeraheni,I, "Penerapan Model Pembelajaran Problem Based Learning untuk. Meningkatkan Kemampuan Berfikir Kritis dan Hasil Belajar Matematika Siswa Kelas 4 SD”. Jurnal Karya Pendidikan Matematika, 5 (1), 2018, 536-548. 
menarik kesimpulan. ${ }^{3}$ Tetapi pada dasarnya dalam menyelesaikan permasalahan pada pembelajaran, khususnya Matematika peserta didik dituntut untuk menyelesaikan dengan cara seperti yang pendidik ajarkan, hal itu dapat menyebabkan cara berfikir peserta didik kurang meluas.

Menurut Wahyudi dan Budiono (2012) Matematika berasal dari bahasa Yunani yaitu mathein atau manthenein yang berarti mempelajari. ${ }^{4}$ Indarwati (2014) mengungkapkan bahwa Matematika merupakan suatu ilmu Universal yang meliputi ide, gagasan dan konsep abstrak yang saling berkaitan pada keseharian manusia, ${ }^{5}$ hal tersebut sesuai dengan sifat yang dimiliki oleh Matematika yakni Matematika merupakan penerapan bidang ilmu keseharian dalam kehidupan manusia. Dari pendapat tersebut dapat disimpulkan bahwa pembelajaran Matematika merupakan pembelajaran yang sangat penting dalam mengembangkan cara berfikir pada peserta didik secara logis yang berkaitan dengan kehidupan sehari-hari. Dalam melatih kemampuan siswa berfikir kritis, salah satunya menggunakan model pembelajaran yang sesuai dengan sifat pembelajaran Matematika.

Menurut Joyce (dalam Trianto Saputra, 2015:23) Model pembelajaran merupakan rencana yang digunakan seseorang sebagai pedoman dalam melaksanakan pembelajaran di kelas. ${ }^{6}$ Dalam menggunakan model pembelajaran tidak sembarang model, tetapi harus memilih model pembelajaran yang dapat melatih siswa berfikir secara logis dalam menyelesaikan masalah, dengan cara itu maka memunculkan pemikiran siswa yang kritis. Salah satu model yang digunakan adalah model pembelajaran Problem Based Learning dan Discovery Learning. Model pembelajaran Problem Based Learning menurut Syahroni (2016:66) merupakan model pembelajaran yang berkaitan dengan masalah nyata peserta didik dari lingkungan, maka dari itu

${ }^{3}$ Wulandari, W., \& Wahyudi, "Efektivitas Model Pembelajaran Problem Solving dan Problem Posing ditinjau dari Kemampuan Berfikir Kritis Matematika Siswa Kelas 4”. Jurnal Sekolah Dasar, 1 (1), 2020, 1-10.

${ }^{4}$ Wahyudi, \& Budiono, I., Pemecahan Masalab Matematika. (Salatiga: Widya Press, 2012).

${ }^{5}$ Indarwati, D., Wahyudi, \& Ratu, N, "Peningkatan Kemampuan Pemecahan Masalah Matematika melalui Penerapan Problem Based Learning untuk Siswa Kelas V SD”. Satya Widya, 30 (1), 2014, 17-27.

${ }^{6}$ Saputra, A. T, "Peningkatan Kemampuan Berfikir Kritis menggunakan Model Problem Based Learning (PBL) pada Pembelajaran Tematik. Terpadu di Sekolah Dasar”. e-Jurnal Inovasi Pembelajaran Sekolah Dasar, 1(1), 2015, 1-16. 
memudahkan dalam pemahaman konsep dan cara berfikir siswa secara kritis. ${ }^{7}$ Terdapat 5 tahap langkah - langkah pembelajaran Problem Based Learning, yaitu: Orientasi siswa dalam masalah, mengorganisasi siswa dalam pembelajaran, membimbing penyelidikan secara individu maupun kelompok, mengembangkan serta menyajikan hasilnya, dan menganalisis serta mengevaluasi proses dan hasil.

Sedangkan model pembelajaran Discovery Learning menurut Hosnan (dalam Yudi dan Tego, 2020:230), merupakan model untuk mengembangkan cara belajar siswa aktif dengan penemuan yang menekankan kemampuan berpikir analitis dan mencoba memecahkan sendiri masalah yang dihadapi. ${ }^{8}$ Menurut Afandi (2013:99) melalui Discovery Learning siswa dapat menguasai metode ilmiah yang nantinya akan dikembangkan siswa sendiri. ${ }^{9}$ Ada beberapa langkah-langkah model pembelajaran Discovery Learning, yaitu; memberikan rangsangan, mengidentifikasi masalah, mengumpulkan data, mengolah data, melakukan pembuktian, dan menarik Kesimpulan. Melalui pengertian kedua model tersebut, maka dapat dikatakan bahwa Problem Based Learning dan Discovery Learning merupakan dua model pembelajaran yang dapat berpengaruh untuk siswa dalam berfikir kritis dalam menyelesaikan masalah.

Permasalahan yang dihadapi dalam penelitian ini adalah, bagaimana menentukan model yang berpengaruh terhadap berfikir kritis siswa pada pembelajaran Matematika. Penelitian ini menuliskan dengan menggunakan model Problem Based Learning dan Discovery Learning. Kedua model tersebut dapat mempengaruhi dalam berfikir kritis siswa, melalui beberapa hasil penelitian sebelumnya. Jika dalam eksperimen dan penelitian tindakan kelas dilakukan menggunakan treatment langsung kepada siswa, maka dalam penelitian ini menggunakan kajian meta-analisis. Tetapi masih terdapat keraguan mengenai penelitian meta-analisis model pembelajaran Problem Based Learning dan Disocvery Learning, maka peneliti mencantumkan beberapa penelitian sebelumnya, dengan tujuan untuk memperkuat penelitian yang akan dilakukan oleh peneliti.

\footnotetext{
7 Syahroni, "Pengaruh Model Problem Based Learning (PBL) terbadap Pemahaman Konsep dan Keterampilan Berfikir Kritis Siswa Kelas IV Jambu Hilir Baluti 2 pada Mata Pelajaran Ilmu Pengetabuan Alam”. Jurnal Pendidikan, 1(1), 2016), 65-71.

${ }^{8}$ Winoto, Y. C., \& Prasetyo, T, "Efektivitas Model Problem Based Learning dan Discovery Learning terbadap Kemampuan Berfikir Kritis Siswa Sekolah Dasar”. Jurnal Basicedu, 4(2), 2020, 228-238.

${ }_{9}$ Afandi, M, Model dan Metode Pembelajaran di Sekolah. (Semarang: Unnisula Press, 2013).
} 
Beberapa penelitian yang sudah dilakukan oleh peneliti lainnya dalam model pembelajaran Problem Based Learning dan Discovery Learning terhadap berfikir kritis, yaitu Penelitian yang dilakukan oleh Anggit Sukmawati (2020) dengan meta analisis Model Problem Based Learning dalam meningkatkan kemampuan berpikir kritis pada pembelajaran Matematika yang menghasilkan bahwa adanya pengaruh model terhadap berfikir kritis pada pembelajaran Matematika. ${ }^{10}$ Sedangkan Umi Mahmudah (2020) melakukan penelitian meta analisis Model Discovery Learning dan Problem Based Learning yang menghasilkan bahwa model pembelajaran secara keseluruhan dapat berpengaruh besar terhadap berfikir kritis, dimana model yang paling efektif adalah model Discovery Learning. ${ }^{11}$

Berdasarkan hasil penelitian sebelumnya yang sudah dipaparkan. Maka penulis tertarik untuk melakukan penelitian dengan judul penelitian "Efektivitas Model Pembelajaran Problem Based Learning dan Discovery Learning terhadap Berfikir Kritis pada Pembelajaran Matematika: Kajian Meta-Analisis" . Peneliti berharap melalui penelitian dua model tersebut, peneliti mampu mengetahui model pembelajaran yang dapat berpengaruh terhadap berfikir kritis siswa pada pembelajaran Matematika.

\section{METODE PENELITIAN}

Dalam penelitian ini menggunakan jenis penelitian meta-analisis. Meta-analisis menurut Indri Anugeraheni (2018:12) adalah sebuah penelitian yang dilakukan oleh peneliti dengan merangkum hasil data penelitian, mereview, serta menganalisis data yang didapatkan sebelumnya. ${ }^{12}$ Variabel yang digunakan pada penelitian ini adalah variabel x yaitu model pembelajaran (Problem Based Learning dan Discovery Learning) serta variabel y yaitu berfikir kritis. Menurut Retnawati (2018) meta-analisis berguna dalam proses merangkum temuan penelitian tetapi peneliti membutuhkan

\footnotetext{
10 Sukmawati, A, "Meta Analisis Model Problem Based Learning dalam Meningkatkan Kemampuan Berfikir Kritis pada Pembelajaran Matematika". Thinking and Creativity Journal, 3(2), 2020, 63-69.

11 Mahmudah, U, "Meta Analisis Pengaruh Model Discovery Learning dan Problem Based Learning terhadap Kemampuan Berfikir Kritis Matematika Peserta Didik Kelas V SD”. Thinking Skills and Creativity Journal, 3(2), 2020, 69-78.

12 Anugeraheni, I, "Meta Analisis Model Pembelajaran Problem Based Learning dalam Meningkatkan Keterampilan Berfikir Kritis di Sekolah Dasar". A Journal of Languange Culture and Education Polygot, 14(1), 2018, 9-18.
} 
pengetahuan yang khusus dalam menyatakan hasilnya di akhir. ${ }^{13}$ Penelitian ini dilakukan dengan cara observasi hasil nilai pretest dan posttest dari beberapa jurnal artikel yang relevan di Google Cendekia. Dari beberapa jurnal relevan yang diperoleh, kemudian dilakukan coding sesuai dengan kriteria yang memenuhi dan diambil datanya, sehingga memperoleh data secara kuantiatif. Berikut ini hasil nilai data yang sudah dikumpulkan untuk dijadikan penelitian, yang disajikan dalam bentuk tabel 1 tentang Indeks Perolehan Reseach gap:

Tabel 1. Indeks Perolehan Reseach gap

\begin{tabular}{rccccccc}
\hline $\begin{array}{r}\text { Kode } \\
\text { Data }\end{array}$ & Pretest & Posttest & Peningkatan & $\begin{array}{r}\text { Kode } \\
\text { Data }\end{array}$ & Pretest & Posttest & Peningkatan \\
\hline PBL 1 & 43,2 & 88,20 & 45,00 & DL 1 & 71,75 & 81,75 & 10,00 \\
PBL 2 & 47,29 & 71,21 & 23,92 & DL 2 & 42,25 & 83,75 & 41,5 \\
PBL 3 & 39,58 & 85,45 & 45,87 & DL 3 & 62,5 & 83,81 & 21,31 \\
PBL 4 & 62,86 & 74,83 & 11,97 & DL 4 & 51,42 & 87,9 & 36,48 \\
PBL 5 & 49,13 & 70,40 & 21,27 & DL 5 & 67,41 & 85,85 & 18,44 \\
PBL 6 & 50,00 & 79,45 & 29,45 & DL 6 & 65,74 & 86,9 & 21,16 \\
PBL 7 & 54,38 & 74,38 & 20,00 & DL 7 & 49,36 & 83,16 & 33,80 \\
PBL 8 & 51,93 & 82,09 & 30,16 & DL 8 & 59,06 & 76,31 & 17,25 \\
PBL 9 & 50,10 & 79,16 & 29,06 & DL 9 & 63,33 & 85,57 & 22,24 \\
PBL 10 & 37,27 & 79,28 & 42,01 & DL 10 & 64,03 & 80,84 & 16,81 \\
Mean & 48,57 & 78,44 & 29,87 & Mean & 59,68 & 83,58 & 23,89 \\
\hline
\end{tabular}

Dalam penelitian ini menggunakan teknik analisis dengan Uji beda rata-rata melalui Uji Ancova yang menggunakan program Statistical Package for Social Science (SPSS). Uji Ancova bertujuan untuk mengetahui apakah ada perbedaan yang signifikan antara kedua model pembelajaran. Dalam melakukan Uji Ancova terlebih dahulu harus dilakukannya Uji statistic, meliputi distribusi data tunggal Univariat pada masing-masing variabel dan Uji Prasayrat, yakni Uji Normalitas untuk mengetahui data berdistribusi normal atau tidak, Uji Homogenitas untuk mengetahui data

13 Retnawati, H., Apino, E., Kartianom, Djidu, H., \& Anazifa, R. D, Pengantar Analisis Meta (Yogyakarta: Parama Publishing, 2018). 
berdistribusi homogen atau heterogen, dan Uji Linearitas untuk mengetahui kedua variabel linear atau tidak. Syarat terpenuhi jika hasil nilai signfiikan $>0,05$. Setelah itu dilakukan Uji Hipotesis dan yang terakhir menentukan Effect siz̨e dengan tujuan untuk mengetahui besarnya skala keefektifan kedua model pembelajaran dengan memperhatikan interprestasi Effect Size.

\section{HASIL DAN PEMBAHASAN}

Penelitian ini dilakukan untuk mengetahui pengaruh tingkat perbedaan model pembelajaran Problem Based Learning dan Discovery Learning terhadap berfikir kritis siswa pada pembelajaran Matematika menggunakan kajian meta-analisis, Artikel jurnal yang dikumpulkan dalam penelitian ini adalah 20 artikel jurnal jenis penelitian yang relevan. Dari seluruh data yang diperoleh maka dilakukannya Uji statistic, meliputi distribusi data tunggal Univariat pada masing-masing variabel, Uji Prasyarat yakni Uji Normalitas, Uji Homogenitas, dan Uji Linearitas. Setelah Uji Prasyarat terpenuhi kemudian dilakukan Uji Ancova beserta Uji Hipotesis untuk menentukan hipotesis diterima atau ditolak. Dan yang terakhir dilakukannya Effect Siže. Dari hasil kinerja kedua model pembelajaran memiliki kinerja yang baik. Kemudian dari hasil Uji Normalitas, Uji Homogenitas, dan Uji Linearitas menghasilkan data yang berdistribusi normal, memiliki variasi yang homogen dan menghasilkan hubungan yang linear signifikan. Hal tersebut diperoleh dari nilai signifikan $>0,05$. Setelah dilakukannya Uji Prasyarat kemudian dilakukannya Uji Ancova. Berikut ini hasil dari Uji Ancova yang disajikan dalam bentuk tabel 2:

Tabel 2. Hasil Analisis Data menggunakan Uji Ancova

\begin{tabular}{lcrr}
\hline \multicolumn{4}{c}{ Descriptive Statistics } \\
\hline Dependent Variable: & Posttest & \\
\hline Kelas & Mean & Std. Deviation & $\mathrm{N}$ \\
\hline Kelas PBL & 78,4450 & 5,83471 & 10 \\
Kelas DL & 83,5840 & 3,37911 & 10 \\
Total & 81,0145 & 5,33709 & 20 \\
\hline
\end{tabular}


Hasil yang diperoleh dari Uji Ancova dengan 20 jurnal penelitian, menghasilkan rata-rata 78,4450 untuk model pembelajaran Problem Based Learning dan 83,5840 untuk model pembelajaran Discovery Learning. Sehingga dapat dinyatakan bahwa adanya perbedaan antara model pembelajaran Problem Based Learning dan Discovery Learning terhadap berfikir kritis pada pembelajaran Matematika, dengan demikian model pembelajaran Discovery Learning lebih tinggi dibandingkan model pembelajaran Problem Based Leaming. Untuk hasil analisis Uji Ancova dinyatakan dalam tabel 3 berikut ini:

Tabel 3. Hasil Analisis Uji Ancova

\begin{tabular}{|c|c|c|c|c|c|c|}
\hline \multicolumn{7}{|c|}{ Tests of Between-Subjects Effects } \\
\hline \multicolumn{7}{|c|}{ Dependent Variable: Posttest } \\
\hline & Type III & & & & & \\
\hline & Sum of & & Mean & & & Partial Eta \\
\hline Source & Squares & df & Square & $\mathrm{F}$ & Sig. & Squared \\
\hline Corrected & $163,548^{\mathrm{a}}$ & 2 & 81,774 & 3,681 &, 047 & ,302 \\
\hline Model & & & & & & \\
\hline Intercept & 3363,990 & 1 & 3363,990 & 151,428 & ,000 & 899 \\
\hline Pretest & 31,502 & 1 & 31,502 & 1,418 & ,250 & ,077 \\
\hline Kelas & 159,529 & 1 & 159,529 & 7,181 & ,016 & ,297 \\
\hline Error & 377,658 & 17 & 22,215 & & & \\
\hline Total & 131808,190 & 20 & & & & \\
\hline Corrected Total & 541,206 & 19 & & & & \\
\hline
\end{tabular}

Dilihat dari Uji Ancova melalui Univariate yang menunjukkan nilai signifikasi 0,016 $<0,05$. Hasil Uji Ancova membuktikan bahwa $\mathrm{F}_{\text {hitung }}>\mathrm{F}_{\text {tabel }}$ yakni dengan nilai 7,181 > 3,59 dan signifikasinya $0,016<0,05$ yang membuktikan bahwa $\mathrm{H}_{\mathrm{o}}$ ditolak dan $\mathrm{H}_{\mathrm{a}}$ diterima. Dari hasil tersebut maka terdapat perbedaan yang signifikan antara model pembelajaran Problem Based Leraning dan Discovery Learning terhadap berfikir kritis siswa pada pembelajaran Matematika. Setelah dilakukannya Uji Ancova, kemudian dilakukannya Effect Size yang tentunya melalui Uji Ancova. Dilihat dalam kolom Partial Eta Squared menyatakan bahwa nilai 0,302 masih diantara nilai 0,21 sampai 0,50 maka 
dari itu dinyatakan memiliki Interprestasi yang sedang. Dan dari signifikasi menunjukkan bahwa model pembelajaran Problem Based Learning dan Discovery Learning memberikan pengaruh yang signifikan terhadap berfikir kritis siswa karena Sig. 0,047 $<$ 0,05. Maka dari itu model pembelajaran Problem Based Learning dan Discovery Learning memberikan pengaruh yang tergolong sedang terhadap berfikir kritis pada pembelajaran Matematika.

\section{KESIMPULAN}

Penelitian dengan judul Efektivitas model pembelajaran Problem Based Learning dan Discovery Learning terhadap berfikir kritis pada pembelajaran Matematika: Kajian Meta-analisis yang menggunakan 20 artikel jurnal membuktikan bahwa model pembelajaran Discovery Learning lebih efektif dibandingkan dengan model pembelajaran Problem Based Learning terhadap berfikir kritis siswa pada pembelajaran Matematika, hal tersebut dibuktikan dari hasil Uji Ancova yang menunjukkan jumlah rata-rata nilai posttest pada model pembelajaran Problem Based Learning lebih tinggi dibandingkan model pembelajaran Discovery Learning. Berdasarakan taksiran Effect Size yang dilihat melalui Partial Eta Square dapat dinyatakan bahwa model pembelajaran Problem Based Learning dan Discovery Learning memberikan pengaruh yang tergolong sedang terhadap berfikir kritis siswa pada pembelajaran Matematika.

\section{DAFTAR PUSTAKA}

Afandi, M. (2013). Model dan Metode Pembelajaran di Sekolah. Semarang: Unnisula Press. Anugeraheni, I. (2018). Meta Analisis Model pembelajaran Problem Based Learning dalam Meningkatkan Keterampilan Berfikir Kritis di Sekolah Dasar. A Journal of Languange http://dx.doi.org/10.19166/pji.v14i1.789

Asriningtyas, A. N., Kristin, F., \& Anugeraheni, I. (2018). Penerapan Model Pembelajaran Problem Based Learning untuk Meningkatkan Kemampuan Berfikir Kritis dan Hasil Belajar Matematika Siswa Kelas 4 SD. Jurnal Karya Pendidikan Matematika , 5 (1), 23-32. https://doi.org/10.26714/jkpm.5.1.2018.23-32

Indarwati, D., Wahyudi, \& Ratu, N. (2014). Peningkatan Kemampuan Pemecahan Masalah Matematika melalui Penerapan Problem Based Learning untuk Siswa 
Kelas V SD. Satya Widya , $30 \quad$ (1), 17-27. https://doi.org/10.24246/j.sw.2014.v30.i1.p17-27

Mahmudah, U. (2020). Meta Analisis Pengaruh Model Discovery Learning dan Problem Based Learning terhadap Kemampuan Berfikir Kritis Matematika Peserta Didik Kelas V SD. Thinking Skills and Creativity Journal , 3 (2), 69-78. http://dx.doi.org/10.23887/tscj.v3i2.29721

Mustofa. (2015). Model Pendidikan dan Pelatihan Konsep dan Aplikasi. Bandung: Alfaberta.

Retnawati, H., Apino, E., Kartianom, Djidu, H., \& Anazifa, R. D. (2018). Pengantar Analisis Meta. Yogyakarta: Parama Publishing.

Saputra, A. T. (2015). Peningkatan Kemampuan Berfikir Kritis menggunakan Model Problem Based Learing (PBL) pada Pembelajaran Tematik Terpadu di Sekolah Dasar. e-Jurnal Inovasi Pembelajaran Sekolah Dasar , 1 (1), 1-16.

http://ejournal.unp.ac.id/students/index.php/pgsd/article/view/2008

Sukmawati, A. (2020). Meta Analisis Model Problem Based Learning dalam Meningkatkan Kemampuan Berfikir Kritis pada Pembelajaran Matematika. Thinking Skills and Creativity Journal , 3 (2), 63-69. http://dx.doi.org/10.23887/tscj.v3i2.30211

Syahroni. (2016). Pengaruh Model Problem Based Learning (PBL) terhadap Pemahaman Konsep dan Keterampilan Berfikir Kritis Siswa Kelas IV Jambu Hilir Baluti 2 pada Mata Pelajaran Ilmu Pengetahuan Alam. Jurnal Pendidikan , 1 (1), 65-71.

http://dx.doi.org/10.26740/jp.v1n1.p66-72

Wahyudi, \& Budiono, I. (2012). Pemecahan Masalab Matematika. Salatiga: Widya Press.

Winoto, Y. C., \& Prasetyo, T. (2020). Efektivitas Model Problem Based Learning dan Discovery Learning terhadap Kemampuan Berfikir Kritis Siswa Sekolah Dasar. Jurnal Basicedu , 4 (2), 228-238. https://doi.org/10.31004/basicedu.v4i2.348

Wulandari, W., \& Wahyudi. (2020). Efektivitas Model Pembelajaran Problem Solving dan Problem Posing ditinjau dari Kemampuan Berfikir Kritis Matematika Siswa Kelas 4. Jurnal Sekolab Dasar , 1 (1), 1-10.

https://doi.org/10.36805/jurnalsekolahdasar.v1i1.890 